\title{
Effect of a High and Low Dose of Caffeine on Antigen-Stimulated Activation of Human Natural Killer Cells After Prolonged Cycling
}

\author{
Deborah K. Fletcher and Nicolette C. Bishop
}

\begin{abstract}
This study investigated the effect of a high and low dose of caffeine on antigen-stimulated natural killer (NK) cell (CD3 $\mathrm{CD}^{2} 6^{+}$) activation after prolonged, strenuous cycling, as assessed by the early-activation molecule CD69. In a randomized crossover design, 12 healthy male endurance-trained cyclists cycled for $90 \mathrm{~min}$ at $70 \% \mathrm{VO}_{2 \text { peak }} 60$ min after ingesting either 0 (PLA), 2 (2CAF), or 6 (6CAF) $\mathrm{mg} / \mathrm{kg}$ body mass of caffeine. Whole blood was stimulated with Pediacel (5 in $1)$ vaccine. A high dose of caffeine $(6 \mathrm{CAF})$ increased the number of $\mathrm{CD}^{-} \mathrm{CD} 56^{+}$cells in the circulation immediately postexercise compared with PLA $(p<.05)$. For both $2 \mathrm{CAF}$ and 6CAF, the geometric mean fluorescence intensity (GMFI) of $\mathrm{CD} 9^{+}$expression on unstimulated $\mathrm{CD} 3{ }^{-} \mathrm{CD} 56^{+}$cells was significantly higher than with PLA (both $p<.05$ ). When cells were stimulated with antigen, the GMFI of CD69 expression remained significantly higher with 2CAF than with PLA $1 \mathrm{hr}$ postexercise $(p<.05)$. Although not achieving statistical significance, 6CAF also followed a similar trend when stimulated $(p=.09)$. There were no differences in GMFI of CD69 expression between 2CAF and 6CAF. These results suggest that a high $(6 \mathrm{mg} / \mathrm{kg})$ dose of caffeine was associated with the recruitment of NK cells into the circulation and that both a high and low $(2 \mathrm{mg} / \mathrm{kg})$ dose of caffeine increased unstimulated and antigen-stimulated NK-cell activation 1 hr after high-intensity exercise. Furthermore, there does not appear to be a dose-dependent effect of caffeine on NK-cell activation $1 \mathrm{hr}$ after prolonged intensive cycling.
\end{abstract}

Keywords: methylxanthine, lymphocytes, immune, exercise

Caffeine is a trimethylxanthine that is legally and socially acceptable and as such is the most widely consumed behavior-influencing substance in the world (Graham, 2001). Many athletes consume caffeine for its known ergogenic effects, and its prevalence is increasing among the athletic population since being legitimized by its recent removal from the World Anti-Doping Agency's list of prohibited substances (Chester \& Wojek, 2008). It has been well documented that caffeine between the doses of 3 and $6 \mathrm{mg} / \mathrm{kg}$ body mass enhance athletic performance (Graham, 2001), but doses as low as $2 \mathrm{mg} / \mathrm{kg}$ body mass ( 150-200 mg) have also been proven ergogenic (Cox et al., 2002; Jenkins, Trilk, Singhal, O’Connor, \& Cureton, 2008).

Natural killer (NK) cells are part of the innate immune system and comprise around 5-20\% of all lymphocytes in peripheral blood (Andoniou, Andrews, \& Degli-Esposti, 2006). These cells are distinct from other lymphocytes because they do not need prior sensitization or require specific antigen recognition to kill target cells. NK cells represent the "first line of defense" against infectious agents, playing a pivotal role in defense against viral infection and tumor immune surveillance (Andoniou et al., 2006). However, these functional responses typically decrease after high-intensity exercise (as reviewed by

The authors are with the School of Sport, Exercise and Health Sciences, Loughborough University, Loughborough, UK.
Gleeson, 2007), and it is thought that this decrement may partly account for the apparent high incidence of viral respiratory infection experienced by some elite athletes. At rest (unstimulated), low levels of functionally active CD69 are expressed on NK cells (Borrego, Robertson, Ritz, Peña, \& Solana, 1999). CD69 is one of the earliest cell-surface antigens expressed by lymphocytes after activation (Ziegler, Ramsdell, \& Alderson, 1994) and once expressed is thought to play an essential role in subsequent cytokine production, proliferation, and cytotoxicity (Borrego et al., 1999; McFarlin, Flynn, Stewart, \& Timmerman, 2004). As such CD69 expression appears to indicate a cell's capability to recognize a potential antigenic/mitogenic threat and begin responding (Green, Rowbottom, \& Mackinnon, 2003).

NK cells express both adenosine receptors $\left(A_{1}, A_{2 A}\right.$, and $\left.A_{2 B}\right)$ and $\beta_{2}$-adrenoreceptors, with the density of these receptors increased after activation (Priebe, Platsoucas, \& Nelson, 1990; Shephard, 2003). Increased concentrations of adenosine and epinephrine have been shown to inhibit NK-cell function in vitro and in vivo (Kappel et al., 1991; Priebe et al., 1990) via activation of adenylate cyclase and increased intracellular cAMP (Raskovalova, Lokshin, Huang, Jackson, \& Gorelik, 2006). Strenuous exercise increases the plasma concentrations of both adenosine and epinephrine (Hartley et al., 1972; Vizi et al., 2002). It follows, therefore, that altering the effects of adenosine and epinephrine during intensive exercise 
could affect subsequent NK-cell responses. Given that caffeine is a nonselective adenosine-receptor antagonist and also stimulates epinephrine release from the adrenal medulla, ingesting caffeine before exercise could influence NK-cell responses after exercise.

Despite the widespread use of caffeine reported among the athletic population to enhance performance, little research has investigated the effect this drug may have on an athlete's immune system after high-intensity exercise and the subsequent risk of infection. Of the handful of studies that have been published to date investigating the effect of caffeine on various immune functions after highintensity exercise, all have used a large $(6 \mathrm{mg} / \mathrm{kg})$ dose of caffeine (Bishop, Smith, Fitzgerald, Porter, \& Scanlon, 2005; Walker, Caudwell, Dixon, \& Bishop, 2006). Many athletes do not consume large amounts of caffeine $(\sim 450$ $\mathrm{mg}$ ) in one bolus dose; instead they tend to ingest much smaller amounts $(\sim 200 \mathrm{mg})$ to enhance performance (Chester \& Wojek, 2008). A study by Kantamala, Vongsakul, and Satayavivad (1990) demonstrated that different doses of caffeine exert differential influences over NK-cell cytotoxic activity in rats at rest. Caffeine doses of 5-40 $\mu \mathrm{g} / \mathrm{ml}$ had little effect on NK-cell cytotoxicity in vitro. However, a 6-mg/kg dose of caffeine in vivo significantly decreased NK-cell function, whereas both 2- and 18-mg/ $\mathrm{kg}$ caffeine doses had no effect. To our knowledge no study to date has investigated the effect of different doses of caffeine on human NK-cell function after a bout of high-intensity exercise. Initial work from our group has shown that ingesting $6 \mathrm{mg} / \mathrm{kg}$ body mass caffeine $1 \mathrm{hr}$ before 90 min of cycling at $70 \% \mathrm{VO}_{2 \text { peak }}$ increases NKcell activation $1 \mathrm{hr}$ postexercise compared with placebo (Fletcher, Bowry, Noon, \& Bishop, 2008). Therefore, the aim of this study was to determine the effect of a high and low dose of caffeine on NK-cell activation after 90 min of cycling at $70 \% \mathrm{VO}_{2 \text { peak }}$, as assessed by the early-activation marker CD69. An initial pilot study was also undertaken to ascertain any effects of the different doses of caffeine on antigen-stimulated NK-cell activation at rest.

\section{Methods}

\section{Participants}

Twelve endurance-trained male cyclists $(M \pm S D$; age 22 \pm 2 years, body mass $71 \pm 6 \mathrm{~kg}, \mathrm{VO}_{2 \text { peak }} 61 \pm 4 \mathrm{ml} \cdot \mathrm{kg}^{-1}$. $\mathrm{min}^{-1}$, peak power output $330 \pm 25 \mathrm{~W}$ ) volunteered to participate in this study. All participants were fully informed about the rationale for the study, along with their possible risks and discomforts, before providing written informed consent. The local ethical advisory committee approved the study. At an initial health screening, participants did not report taking any medications or experiencing any symptoms of upper respiratory tract infection in the 4 weeks before the study. They also completed a physical activity questionnaire and a caffeine-consumption questionnaire during the initial screening. Before each additional laboratory visit a subsequent health-screening questionnaire was administered. Daily caffeine intake among participants varied and ranged from 30 to 359 $\mathrm{mg} /$ day. One participant was characterized as a high user (>250 mg/day), 6 as moderate users (50-250 mg/day), and 5 as light users $(<50 \mathrm{mg} /$ day $)$.

\section{Pilot Study}

Before the preliminary testing took place, a resting pilot study was undertaken to determine whether there was any effect of caffeine at a dose of 0,2 , or $6 \mathrm{mg} / \mathrm{kg}$ body mass on unstimulated and antigen-stimulated lymphocyte activation (as assessed by the early-activation molecule CD69). Six healthy participants (age $25 \pm 3$ years, weight $76 \pm 6 \mathrm{~kg}$ ) were randomly assigned to the placebo (PLA), $2-\mathrm{mg} / \mathrm{kg}$ body mass caffeine (2CAF), or $6-\mathrm{mg} / \mathrm{kg}$ body mass caffeine (6CAF) trial and acted as their own controls. Participants reported to the laboratory at 8:20 a.m. under the same conditions as in the exercise trial. They rested quietly in the laboratory for $3.5 \mathrm{hr}$, during which time blood samples were collected to coincide with time points during the main exercise trials (presupplement, preexercise, postexercise, and $1 \mathrm{hr}$ postexercise). The results from this group of participants are shown in Table 1. The number of CD3-CD56 ${ }^{+}$cells was higher $1 \mathrm{hr}$ and $2.5 \mathrm{hr}$ after caffeine ingestion with 6CAF than with PLA or $2 \mathrm{CAF}(p<.05$; Table 1). 6CAF also increased the number of antigen-stimulated $\mathrm{CD} 3{ }^{-} \mathrm{CD} 56^{+}$cells expressing CD69 $1 \mathrm{hr}$ after caffeine ingestion compared with PLA (1:4,000, $p$ <.05; Table 1) and 2CAF (1:8,000, $p<.05$; Table 1). Regardless of caffeine dose, caffeine ingestion did not affect the geometric mean fluorescence intensity (GMFI) of CD69 expression on unstimulated or antigen-stimulated $\mathrm{CD}^{-}{ }^{-} \mathrm{CD}^{2} 6^{+}$cells.

\section{Preliminary Testing}

Approximately 2 weeks before the main trials began, participants were required to perform a continuous incremental exercise test to volitional fatigue on an electromagnetically braked cycle ergometer (Lode Excalibur, Groningen, Netherlands) to determine their peak oxygen consumption $\left(\mathrm{VO}_{2 \text { peak }}\right)$. They started cycling at a work rate of $95 \mathrm{~W}$, with $35-\mathrm{W}$ increments every 3 min, continuing until they reached volitional exhaustion. Expired-gas samples were collected into Douglas bags during the third minute of each work-rate increment and the last minute of the exercise test, with heart rates being measured continuously via short-range radio telemetry (Polar FS1, Polar Electro Oy, Kempele, Finland). A paramagnetic $\mathrm{O}_{2}$ analyzer (Servomex 1420B, Crowborough, $\mathrm{UK}$ ) and an infrared $\mathrm{CO}_{2}$ analyzer (Servomex 1415B) were used to measure the percentages of $\mathrm{O}_{2}$ and $\mathrm{CO}_{2}$ in the expired-gas samples. The analyzers, along with a dry gas meter (Harvard Apparatus, Edenbridge, UK), were used to determine minute ventilation, $\mathrm{O}_{2}$ consumption, and $\mathrm{CO}_{2}$ production. A work rate equivalent to $70 \%$ $\mathrm{VO}_{\text {2peak }}$ for each participant was interpolated from the $\mathrm{VO}_{2}$ $(\mathrm{L} / \mathrm{min})$-work rate $(\mathrm{W})$ relationship. Participants then came back into the laboratory on a separate occasion to 
Table 1 Data From Pilot Study, $M(S D)$

\begin{tabular}{|c|c|c|c|c|}
\hline & $0 \mathrm{hr}$ & $1 \mathrm{hr}$ & $2.5 \mathrm{hr}$ & $3.5 \mathrm{hr}$ \\
\hline \multicolumn{5}{|c|}{ Serum caffeine concentration $(\mu \mathrm{mol} / \mathrm{L})$} \\
\hline PLA & $0(0)$ & $0(0)$ & $0(0)$ & $0(0)$ \\
\hline $2 \mathrm{CAF}$ & $0(0)$ & $16(8) \# \dagger$ & $17(3) \# \dagger$ & $15(3) \# \dagger$ \\
\hline $6 \mathrm{CAF}$ & $0(0)$ & $48(11)^{* \dagger}$ & $47(11)^{* \dagger}$ & $43(9)^{* \dagger}$ \\
\hline \multicolumn{5}{|c|}{ Lymphocytes $\left(\times 10^{9}\right.$ cells/L) } \\
\hline PLA & $1.90(0.30)$ & $1.70(0.20)$ & $1.70(0.30)$ & $1.70(0.30)$ \\
\hline $2 \mathrm{CAF}$ & $1.80(0.40)$ & $1.60(0.40)$ & $1.70(0.30)$ & $1.80(0.30)$ \\
\hline $6 \mathrm{CAF}$ & $1.80(0.30)$ & $2.00(0.30)$ & $1.80(0.50)$ & $1.60(0.30)$ \\
\hline \multicolumn{5}{|c|}{$\mathrm{CD}^{-}{ }^{-} \mathrm{CD}^{2} 6^{+}$cells $\left(\times 10^{9}\right.$ cells $\left./ \mathrm{L}\right)$} \\
\hline PLA & $0.30(0.12)$ & $0.22(0.07)$ & $0.28(0.11)$ & $0.30(0.16)$ \\
\hline $2 \mathrm{CAF}$ & $0.22(0.09)$ & $0.21(0.07)$ & $0.20(0.10)$ & $0.30(0.13)$ \\
\hline $6 \mathrm{CAF}$ & $0.29(0.11)$ & $0.41(0.17)^{* * \dagger \dagger}$ & $0.37(0.07)^{* *}$ & $0.30(0.06)$ \\
\hline \multicolumn{5}{|c|}{$\mathrm{CD}^{-}{ }^{-} \mathrm{CD} 56^{+} \mathrm{CD}^{-} 9^{+}$cells $\left(\times 10^{6}\right.$ cells $\left./ \mathrm{L}\right)$} \\
\hline unstimulated PLA & $27.25(27.37)$ & $16.73(13.46)$ & $24.00(18.97)$ & $35.39(27.21)$ \\
\hline unstimulated $2 \mathrm{CAF}$ & $25.60(25.90)$ & $28.52(31.77)$ & $28.70(36.05)$ & $30.18(34.85)$ \\
\hline unstimulated $6 \mathrm{CAF}$ & $54.27(53.51)$ & $23.62(45.35)$ & $55.22(45.20)$ & $33.81(24.71)$ \\
\hline 1:4,000 PLA & $49.80(30.34)$ & $31.16(18.84)$ & $47.72(22.09)$ & $61.52(37.38)$ \\
\hline $1: 4,0002 \mathrm{CAF}$ & $32.88(18.81)$ & $55.45(47.82)$ & $49.21(37.71)$ & $96.12(96.79)$ \\
\hline $1: 4,0006 \mathrm{CAF}$ & $46.55(14.02)$ & $68.02(28.54) \ddagger$ & $80.83(33.30) \dagger \dagger$ & $61.75(30.13)$ \\
\hline 1:8,000 PLA & $38.82(24.63)$ & $41.60(34.46)$ & $43.23(21.72)$ & $57.02(32.82)$ \\
\hline $1: 8,0002 \mathrm{CAF}$ & $33.04(29.53)$ & $29.76(22.69)$ & $29.51(29.38)$ & $62.34(59.89)$ \\
\hline $1: 8,0006 \mathrm{CAF}$ & $50.78(60.98)$ & $47.09(29.34) \S$ & $60.87(43.34) \dagger \dagger$ & $54.94(21.33)$ \\
\hline \multicolumn{5}{|c|}{$\mathrm{CD}^{-}{ }^{-} \mathrm{CD} 56^{+} \mathrm{CD} 9^{+} \mathrm{GMFI}$} \\
\hline unstimulated PLA & $100(0)$ & $97(11)$ & 103 (17) & $100(17)$ \\
\hline unstimulated $2 \mathrm{CAF}$ & $100(0)$ & $115(30)$ & $104(22)$ & $111(28)$ \\
\hline unstimulated 6CAF & $100(0)$ & $100(11)$ & $112(30)$ & $109(23)$ \\
\hline 1:4,000 PLA & $100(0)$ & $107(14)$ & $119(17)$ & $119(28)$ \\
\hline $1: 4,0002 \mathrm{CAF}$ & $100(0)$ & $100(16)$ & $101(18)$ & $115(21)$ \\
\hline $1: 4,0006 \mathrm{CAF}$ & $100(0)$ & $105(9)$ & $111(20)$ & $121(34)$ \\
\hline 1:8,000 PLA & $100(0)$ & $117(36)$ & $120(28)$ & $132(55)$ \\
\hline $1: 8,0002 \mathrm{CAF}$ & $100(0)$ & 107 (12) & 109 (16) & $113(12)$ \\
\hline $1: 8,0006 \mathrm{CAF}$ & $100(0)$ & $107(13)$ & $113(17)$ & $116(29)$ \\
\hline
\end{tabular}

Note. PLA $=0 \mathrm{mg} / \mathrm{kg}$ body mass of caffeine; $2 \mathrm{CAF}=2 \mathrm{mg} / \mathrm{kg}$ body mass of caffeine; $6 \mathrm{CAF}=6 \mathrm{mg} / \mathrm{kg}$ body mass of caffeine; $\mathrm{GMFI}=\mathrm{geometric}$ mean fluorescence intensity. The GMFI values are expressed as a percentage relative to presupplement $(0 \mathrm{hr})$ value.

${ }^{*} p<.01, * * p<.05$ : significantly higher on 6CAF than PLA and 2CAF. \#Significantly higher on 2CAF than PLA, $p<.01$. $\ddagger$ Significantly higher on $6 \mathrm{CAF}$ than PLA, $p<.05$. §Significantly higher on 6CAF than $2 \mathrm{CAF}, p<.05 . \dagger p<.01,{ }^{\dagger \dagger} p<.05$ : significantly higher than 0 hr within trial.

undertake a familiarization trial. The familiarization trial required them to cycle for $90 \mathrm{~min}$ at $70 \% \mathrm{VO}_{2 \text { peak }}$ on an electromagnetically braked cycle ergometer. Heart rate was monitored continuously during the familiarization trial, and 1-min expired-gas samples were collected at 20-min intervals throughout to ensure that participants were exercising at the correct intensity.

\section{Experimental Trial Procedures}

Each participant was given a list of caffeine-containing foods and beverages and instructed to abstain from these for $60 \mathrm{hr}$ before each main trial. Participants were also instructed to avoid alcohol consumption and strenuous physical activity in the $24 \mathrm{hr}$ preceding each experimental 
trial. In an attempt to standardize nutritional status, participants completed a $24-\mathrm{hr}$ food diary the day before the first main trial and were asked to follow this during the $24 \mathrm{hr}$ preceding the second and third main trials. They performed three main exercise trials, with 1 week between trials. Participants were randomly assigned to the PLA, 2CAF, or 6CAF trial and acted as their own controls in a repeated-measures, single-blind, crossover design. They arrived at the laboratory at 8:20 a.m. after an overnight fast of $12 \mathrm{hr}$. After $10 \mathrm{~min}$ of resting quietly an initial (presupplement) blood sample was obtained from an antecubital forearm vein by venipuncture. After the blood sample, participants ingested 0,2 , or $6 \mathrm{mg} / \mathrm{kg}$ body mass of caffeine powder (BDH Laboratory Supplies, Poole, UK) taken in the form of cellulose capsules (G \& G Food Supplies Ltd., West Sussex, UK) with $300 \mathrm{ml}$ plain water. For the 0 (PLA) trial, participants ingested 6 $\mathrm{mg} / \mathrm{kg}$ body mass of dextrose powder (BDH Laboratory Supplies). They then rested quietly in the laboratory for $1 \mathrm{hr}$ before a further (preexercise) venous blood sample was taken, after which preexercise body mass (in shorts only) was recorded. Immediately after this, participants began cycling on an electromagnetically braked cycle ergometer for $90 \mathrm{~min}$ at a work rate equivalent to $70 \%$ $\mathrm{VO}_{2 \text { peak }}(213 \pm 22 \mathrm{~W})$. During the 90 -min cycle, their heart rate was recorded every $15 \mathrm{~min}$. Participants also consumed $2 \mathrm{ml} / \mathrm{kg}$ body mass of plain water every 15 min throughout the exercise in an attempt to standardize fluid intake. At 20, 50, and $80 \mathrm{~min}$ of exercise, 1-min expired-gas samples were collected to determine $\mathrm{VO}_{2}$ and $\mathrm{VCO}_{2}$ to ensure that participants were exercising at the required intensity and to allow estimation of fat and carbohydrate oxidation, as well as energy expenditure using stoichiometric equations. A further venous blood sample (postexercise) was obtained immediately after cessation of $90 \mathrm{~min}$ of exercise, before postexercise body mass (in shorts only) was recorded. Participants then consumed $5 \mathrm{ml} / \mathrm{kg}$ body mass of plain water and rested quietly in the laboratory for another hour before a final venous blood sample (1 $\mathrm{hr}$ postexercise) was obtained. During this time no additional food or fluid was administered to participants. For all venous blood samples, 20 $\mathrm{ml}$ of blood was obtained, with all samples taken from participants in an upright seated position. Laboratory conditions throughout the study were $19.6 \pm 0.5^{\circ} \mathrm{C}$ and $35.7 \% \pm 5.4 \%$ relative humidity.

\section{Total Lymphocyte Count and Plasma Volume}

Blood samples were collected into three evacuated monovette tubes (Starstedt, Leicester, UK), one containing $\mathrm{K}_{3}$ EDTA (1.6 mg EDTA/ml blood), one containing lithium heparin (16 IU heparin/ml blood), and one containing no additive to obtain serum, as well as a sterile 5-ml bijou tube (Sterilin, Staffordshire, UK) containing $15 \mu \mathrm{l}$ heparin (15 IU heparin/ml blood). Blood collected into the $\mathrm{K}_{3}$ EDTA monovette $(7.5 \mathrm{ml})$ was analyzed for total and differential leukocyte counts and hematocrit and hemoglobin contents using a hematology analyzer $($ Ac $\bullet$ T 5 diff analyzer, Beckman Coulter, UK). Plasma volume changes were estimated according to Dill and Costill (1974).

\section{Lymphocyte Culture}

Five milliliters of whole blood transferred into the sterile bijou tube containing heparin were immediately placed on ice and mixed (Thermo Denley, Spiramix) for 20 min before setting up cultures as follows: Cells were cultured in Falcon $12 \times 75-\mathrm{mm}$ polystyrene tubes with caps (Becton Dickinson Biosciences, Oxford, UK), and for all samples stimulated and unstimulated cultures were set up. Tubes were stimulated by a 1:400 or 1:800 Pediacel vaccine (Sanofi Pasteur MSD Ltd., Berkshire, UK) containing diphtheria toxoid, tetanus toxoid, acellular pertussis bacteria, poliovirus, and Haemophilus influenza Type B. Zero or $20 \mu \mathrm{l}$ of Pediacel working vaccine (either 1:400 or 1:800) was added to $200 \mu$ l of heparinized whole blood, giving a final stimulant concentration of 1:4,000 (optimum) or 1:8,000 (suboptimum), before being incubated for $20 \mathrm{hr}$ at $37^{\circ} \mathrm{C}, 5 \% \mathrm{CO}_{2}$.

\section{Assessment of Lymphocyte Subsets and CD69 Expression}

After incubation, peripheral blood cells were labeled with a cocktail of Pharmingen monoclonal antibodies (Becton Dickinson Biosciences, Oxford, UK) against human lymphocyte cell-surface markers, as follows: 5 $\mu 1$ CD3 FITC, $20 \mu 1$ CD56 PECy5, and $10 \mu 1$ CD69 PE. All samples were then vortexed and placed on ice for 20 min, after which erythrocytes were lysed and leukocytes fixed using FACS Lyse (Becton Dickinson). Leukocytes were washed once in $3 \mathrm{ml}$ ice-cold phosphate-buffered saline containing $0.1 \%$ bovine serum albumin and $2 \mathrm{mM}$ EDTA before being resuspended in $400 \mu \mathrm{l}$ of this solution. Three-color flow-cytometric analysis was performed using a FACS Calibur flow cytometer with Cell Quest analysis software (Becton Dickinson). Standard gating procedures using side-scatter versus forward-scatter plots were used to gate on the lymphocyte population. An unstained unstimulated sample was used to set quadrant boundaries to allow accurate acquisition of stained samples. All samples were set to collect 30,000 lymphocyte events per analysis.

$\mathrm{CD}^{+}$(T-cell region) and $\mathrm{CD}^{2} 6^{+}$(NK-cell region) populations were acquired on quadrant dot plots of FL1 (CD3 FITC) and FL3 (CD56 PE-Cy5), along with quadrant dot plots of FL1 (CD3) and FL2 (CD69 PE) and quadrant dot plots of FL3 (CD56) and FL2 (CD69). These data were then displayed as histogram plots, the percentage of $\mathrm{CD}^{-}$cells (total lymphocyte region minus the $\mathrm{CD}^{+}$region) expressing $\mathrm{CD}^{+} 6^{+}$was derived, and from this the percentage of total lymphocytes that were $\mathrm{CD}^{-}{ }^{-} \mathrm{CD} 56^{+}$was determined. $\mathrm{CD} 3^{-} \mathrm{CD} 56^{+}$cells were then gated into a separate region, and a $\mathrm{CD} 69^{+}$histogram plot (Figure 1) of the cells in this region was used to calculate 


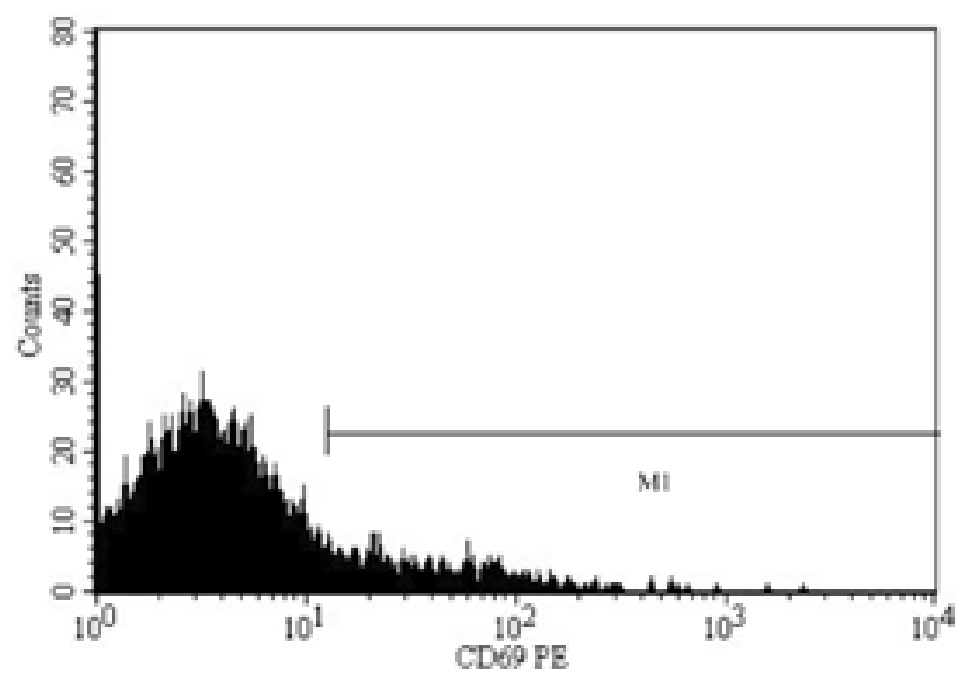

Figure 1 - Histogram of CD69 expression on CD3-CD56 ${ }^{+} \mathrm{NK}$ cells.

the percentage expression and GMFI expression of

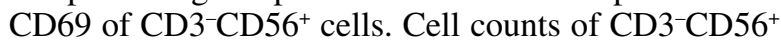
were calculated by multiplying the percentage of these cells with the absolute lymphocyte count. The number of $\mathrm{CD}^{-}{ }^{-} \mathrm{CD} 56^{+}$cells expressing CD69 was determined by multiplying the percentage of cells expressing CD69 by the total number of $\mathrm{CD}^{-}{ }^{-} \mathrm{CD} 56^{+}$cells. To facilitate intersubject comparisons, preexercise, postexercise, and $1 \mathrm{hr}$ postexercise CD69 GMFI were expressed as a percentage of the presupplement value, as per Timmons, Tarnopolsky, Snider, and Bar-Or (2006).

\section{Serum Caffeine and Plasma Cortisol Concentration}

Serum was obtained from whole blood collected into a serum monovette $(5.5 \mathrm{ml})$, which was left to clot for $1 \mathrm{hr}$ before being centrifuged at $1,500 \mathrm{~g}$ for $10 \mathrm{~min}$ in a refrigerated centrifuge at $4{ }^{\circ} \mathrm{C}$. Serum caffeine concentration was determined using a commercially available kit (Emit Caffeine Assay, Dade-Behring, Milton Keynes, UK) on an automatic photometric analyzer (COBAS Miras Plus, Roche Diagnostic Systems, Switzerland). Heparinized plasma was obtained from blood collected into a lithium heparin monovette $(7.5 \mathrm{ml})$. Samples were spun at 1,500 $g$ for $10 \mathrm{~min}$ in a refrigerated centrifuge at $4^{\circ} \mathrm{C}$. Plasma cortisol concentration was determined by ELISA (DRG Diagnostics, DRG Instruments, Germany). The intraassay coefficients of variation for serum caffeine and plasma cortisol were $2.5 \%$ and $1.8 \%$, respectively.

\section{Statistical Analysis}

Data in the text, tables, and figures are presented as $M \pm S D$. The data were examined using a two-factor (Trial $\times$ Time) analysis of variance (ANOVA) with repeated-measures design. If the data were not normally distributed, statistical analysis was carried out on the logarithmic transformation of the data. Assumptions of sphericity in the data were checked, and adjustments in the degrees of freedom for the ANOVA were made using the Huynh-Feldt method of correction where appropriate. Any significant data were assessed using Student's paired $t$ tests with Holm-Bonferroni adjustments for multiple comparisons. Single comparisons between trials for overall exercise intensity, carbohydrate and fat oxidation rates, rate of energy expenditure, and percentage contribution of substrate to energy expenditure were assessed using Student's paired $t$ tests. Statistical significance for this study was accepted at $p<.05$. The observed powers of the reported main and interaction effects are all $>.8$.

\section{Results}

Mean exercise intensity was similar between all trials (Table 2). Heart rates were comparable between trials during exercise (Table 2). Respiratory-exchange ratio and fat and carbohydrate oxidation rates did not differ between trials throughout exercise (Table 2). Likewise, energy expenditure and the percentage contribution of fat and carbohydrate were similar on all trials (Table 2).

After exercise, change in body mass (corrected for fluid intake) was similar for all trials (Table 2). There was no significant Time $\times$ Trial interaction effect for changes in plasma volume relative to the initial blood sample. However, after exercise plasma volume decreased on all trials (Table 2).

A significant Time $\times$ Trial interaction was found for serum caffeine concentration $(p<.01)$, with higher concentrations pre-, post-, and $1 \mathrm{hr}$ postexercise with 6 CAF than with PLA and 2CAF ( $p<.01$; Figure 2$)$. At these times, values with $2 \mathrm{CAF}$ were significantly higher than with PLA $(p<.01$; Figure 2$)$. There were no significant Time $\times$ Trial interaction effects for plasma cortisol 
Table 2 Physiological Variables, Respiratory-Exchange Ratio, Substrate Oxidation, and Energy Expenditure, $M(S D)$

\begin{tabular}{lccc}
\hline & PLA & 2CAF & 6CAF \\
\hline Exercise intensity $\left(\% \mathrm{VO}_{\text {2peak }}\right)$ & $72.0(3.2)$ & $72.8(3.3)$ & $73.3(3.3)$ \\
Heart rate (beats/min) & $155(9)$ & $159(8)$ & $161(8)$ \\
Respiratory-exchange ratio & $0.92(0.05)$ & $0.92(0.06)$ & $0.92(0.06)$ \\
Fat oxidation rate $(\mathrm{g} / \mathrm{min})$ & $0.45(0.29)$ & $0.46(0.30)$ & $0.48(0.29)$ \\
Carbohydrate oxidation rate $(\mathrm{g} / \mathrm{min})$ & $2.67(0.61)$ & $2.69(0.57)$ & $2.69(0.59)$ \\
Energy expenditure $(\mathrm{KJ} / \mathrm{min})$ & $63(3)$ & $64(4)$ & $64(4)$ \\
$\%$ contribution fat & $27(17)$ & $28(18)$ & $29(18)$ \\
$\%$ contribution carbohydrate & $73(17)$ & $72(18)$ & $71(18)$ \\
Body-mass change $(\mathrm{kg})$ & $-1.5(0.3)$ & $-1.6(0.3)$ & $-1.6(0.3)$ \\
Plasma volume change $(\%)$ & $-8.2(5.2)$ & $-8.0(5.0)$ & $-8.5(5.4)$ \\
\hline
\end{tabular}

Note. $\mathrm{PLA}=0 \mathrm{mg} / \mathrm{kg}$ body mass of caffeine; $2 \mathrm{CAF}=2 \mathrm{mg} / \mathrm{kg}$ body mass of caffeine; $6 \mathrm{CAF}=6$ $\mathrm{mg} / \mathrm{kg}$ body mass of caffeine. Values are mean of all recordings throughout exercise $(S D)$.

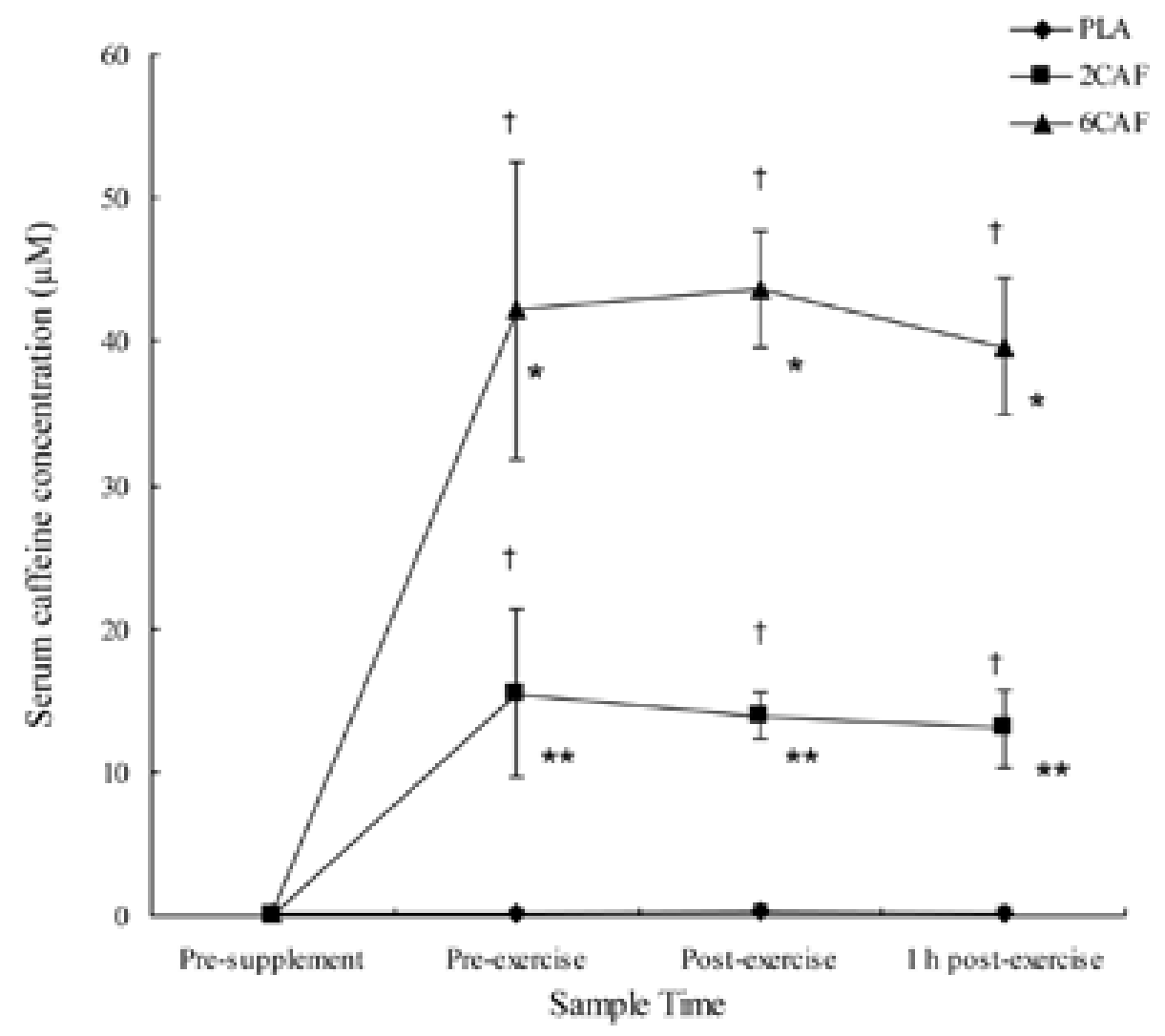

Figure 2 - Serum caffeine concentrations during PLA ( $0 \mathrm{mg} / \mathrm{kg}$ body mass of caffeine), $2 \mathrm{CAF}$ ( $2 \mathrm{mg} / \mathrm{kg}$ body mass of caffeine), and 6CAF $(6 \mathrm{mg} / \mathrm{kg}$ body mass of caffeine) trials, $M \pm S D$. *Significantly higher on 6CAF than PLA and 2CAF $(p<.01) * * \operatorname{Sig}-$ nificantly higher on 2CAF than PLA $(p<.01)$. †Significantly higher than presupplement within trial $(p<.01)$.

concentration for any of the trial comparisons. However, there was a main effect for trial $(p<.01)$, with plasma cortisol concentrations with 6CAF significantly higher overall than with PLA (Table 3).
No significant Time $\times$ Trial interaction effect was found for total number of circulating lymphocytes, but there was a significant main effect for time $(p<.01)$, with the circulating number of lymphocytes following 
Table 3 Plasma Cortisol Concentration, Total Lymphocyte Count, Number of Circulating CD3-
CD56 ${ }^{+}$Cells and Number of Circulating CD3-CD56+ Cells Expressing CD69, $M(S D)$

\begin{tabular}{|c|c|c|c|c|}
\hline & Presupplement & Preexercise & Postexercise & $1 \mathrm{hr}$ postexercise \\
\hline \multicolumn{5}{|c|}{ Plasma cortisol concentration $(\mathrm{nmol} / \mathrm{L})^{\mathrm{a}, \mathrm{b}}$} \\
\hline PLA & $479(68)$ & $375(91)$ & $443(155)$ & $380(131)$ \\
\hline $2 \mathrm{CAF}$ & $477(69)$ & $350(102)$ & $502(191)$ & 409 (156) \\
\hline $6 \mathrm{CAF}$ & $491(67)$ & $389(55)$ & $518(148)$ & $468(114)$ \\
\hline \multicolumn{5}{|c|}{ Lymphocytes $\left(\times 10^{9} \text { cells } / \mathrm{L}\right)^{\mathrm{c}}$} \\
\hline PLA & $2.10(0.60)$ & $1.70(0.40)$ & $2.30(0.80)$ & $1.50(0.40)$ \\
\hline 2CAF & $2.10(0.50)$ & $1.80(0.40)$ & $2.50(0.70)$ & $1.50(0.40)$ \\
\hline $6 \mathrm{CAF}$ & $2.10(0.60)$ & $1.90(0.40)$ & $2.70(1.10)$ & $1.50(0.40)$ \\
\hline \multicolumn{5}{|c|}{$\mathrm{CD}^{-} \mathrm{CD}^{-} 6^{+} \mathrm{CD} 9^{+}$cells $\left(\times 10^{9} \text { cells } / \mathrm{L}\right)^{\mathrm{d}, \mathrm{e}}$} \\
\hline PLA & $0.39(0.17)$ & $0.33(0.16)$ & $0.62(0.30) \dagger \dagger$ & $0.28(0.12) \dagger \dagger$ \\
\hline $2 \mathrm{CAF}$ & $0.42(0.16)$ & $0.39(0.15)$ & $0.68(0.30)$ & $0.25(0.11)$ \\
\hline $6 \mathrm{CAF}$ & $0.42(0.24)$ & $0.43(0.19)$ & $0.79(0.36)^{*}+$ & $0.31(0.14)$ \\
\hline \multicolumn{5}{|c|}{ Unstimulated $\mathrm{CD}^{-}{ }^{-} \mathrm{CD} 6^{+} \mathrm{CD}^{+} 9^{+}$cells $\left(\times 10^{6} \text { cells } / \mathrm{L}\right)^{\mathrm{d}, \mathrm{e}}$} \\
\hline PLA & $39.77(33.09)$ & $30.21(23.03)$ & $49.08(34.96)$ & $20.64(13.54)$ \\
\hline 2CAF & $34.24(22.83)$ & $31.31(17.98)$ & $55.50(45.06)$ & $19.25(15.25)$ \\
\hline $6 \mathrm{CAF}$ & $34.42(19.69)$ & $39.51(23.92)$ & $65.09(32.28)$ & $23.86(14.80)$ \\
\hline \multicolumn{5}{|c|}{ 1:4,000 CD3 ${ }^{-} \mathrm{CD} 6^{+} \mathrm{CD}^{+} 9^{+}$cells $\left(\times 10^{6} \text { cells } / \mathrm{L}\right)^{\mathrm{d}}$} \\
\hline PLA & $47.74(21.97)$ & $41.95(22.16)$ & $82.38(40.11)$ & $42.14(24.25)$ \\
\hline $2 \mathrm{CAF}$ & $49.53(24.04)$ & $65.76(39.63)$ & $95.35(63.38)$ & $39.30(26.05)$ \\
\hline $6 \mathrm{CAF}$ & $53.57(25.63)$ & $75.78(70.33)$ & $97.94(30.69)$ & $41.76(24.66)$ \\
\hline \multicolumn{5}{|c|}{ 1:8,000 CD3 ${ }^{-} \mathrm{CD} 6^{+} \mathrm{CD}^{+} 9^{+}$cells $\left(\times 10^{6} \text { cells } / \mathrm{L}\right)^{\mathrm{d}}$} \\
\hline PLA & $37.88(17.30)$ & $41.46(23.29)$ & $69.51(37.43)$ & $26.16(15.38)$ \\
\hline $2 \mathrm{CAF}$ & $40.65(20.54)$ & $55.58(31.05)$ & $75.19(50.90)$ & $28.24(25.63)$ \\
\hline $6 \mathrm{CAF}$ & $40.31(27.43)$ & $61.80(63.82)$ & $78.97(45.52)$ & $32.67(21.90)$ \\
\hline
\end{tabular}

Note. $\mathrm{PLA}=0 \mathrm{mg} / \mathrm{kg}$ body mass of caffeine; $2 \mathrm{CAF}=2 \mathrm{mg} / \mathrm{kg}$ body mass of caffeine; $6 \mathrm{CAF}=6 \mathrm{mg} / \mathrm{kg}$ body mass of caffeine.

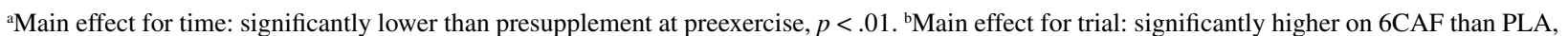
$p<.01$. ${ }^{\mathrm{c}}$ Main effect for time: significantly different from presupplement at preexercise, postexercise, and $1 \mathrm{hr}$ postexercise, $p<.01$. ${ }^{\mathrm{d}}$ Main effect for time: significantly different from presupplement at postexercise and $1 \mathrm{hr}$ postexercise, $p<.01$. ${ }^{\mathrm{e}}$ Main effect for trial: significantly higher on 6 CAF than PLA and 2CAF, $p<.05$.

$* p<.05$ : significantly higher on 6 CAF than PLA. $\dagger p<.01, \dagger \dagger p<.05$ : significantly different than presupplement within trial.

a biphasic response to exercise (Table 3). A significant Time $\times$ Trial interaction was found for the number of $\mathrm{CD}^{-} \mathrm{CD}^{-} 6^{+}$cells in the circulating lymphocyte population, with values higher with 6CAF postexercise than with PLA $(p<.01$; Table 3$)$. 6CAF also showed a higher number of $\mathrm{CD}^{-} \mathrm{CD} 56^{+}$cells in the circulating lymphocyte population than did 2CAF (main effect for trial; $p<.05$ ).

There were no significant Time $\times$ Trial interaction effects for the number of unstimulated or antigenstimulated $\mathrm{CD}^{-}{ }^{-} \mathrm{CD} 56^{+}$cells expressing CD69 for any of the trial comparisons. However, the number of unstimulated and antigen-stimulated $\mathrm{CD}^{-}{ }^{-} \mathrm{CD} 56^{+}$cells expressing CD69 increased above presupplement values at postexercise and decreased below baseline $1 \mathrm{hr}$ postexercise (main effect for time: $p<.01$; Table 3 ).

There was a significant interaction effect for the GMFI of CD69 expression on unstimulated CD3-CD56 ${ }^{+}$ cells, with both $2 \mathrm{CAF}$ and $6 \mathrm{CAF}$ demonstrating a significant increase $1 \mathrm{hr}$ postexercise compared with PLA (both $p<.05$; Figure 3[a]). Values with 2CAF also appeared to be higher than with PLA preexercise; this approached significance $(p=.061)$. GMFI of CD69 expression on unstimulated $\mathrm{CD} 3{ }^{-} \mathrm{CD} 56^{+}$cells was also higher overall with 2CAF than 6CAF (main effect for trial, $p<.05$; Figure 3[a]). When cells were stimulated, GMFI of CD69 expression on antigen-stimulated $(1: 4,000) \mathrm{CD}^{-}{ }^{-} \mathrm{CD} 56^{+}$ cells tended to be higher with 6CAF than PLA ( $p$ for 


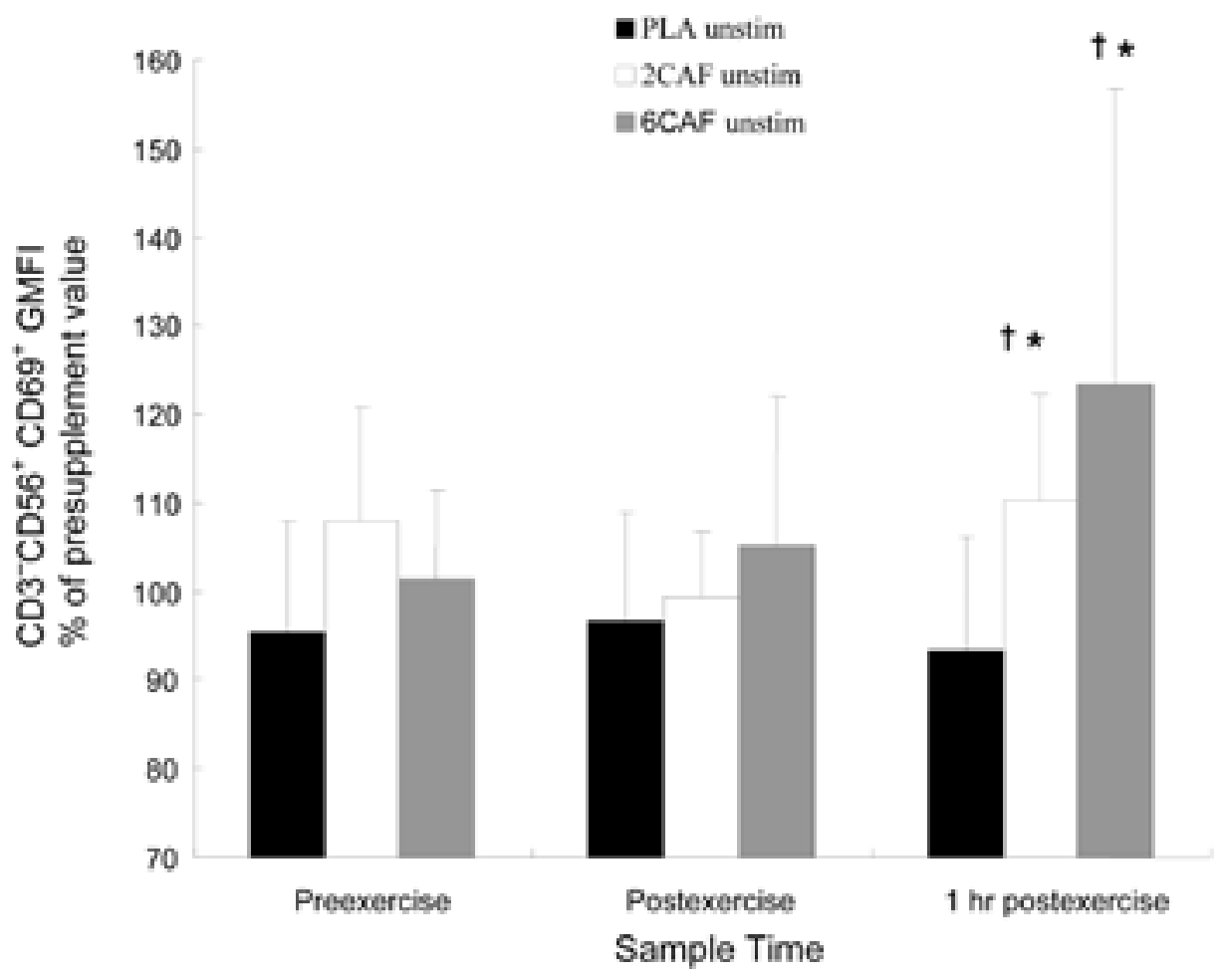

Figure 3(a) - Geometric mean fluorescence intensity of CD69 expression on unstimulated CD3-CD56 ${ }^{+}$natural killer cells within the circulating lymphocyte population during PLA $(0 \mathrm{mg} / \mathrm{kg}$ body mass of caffeine), 2CAF ( $2 \mathrm{mg} / \mathrm{kg}$ body mass of caffeine), and $6 \mathrm{CAF}(6 \mathrm{mg} / \mathrm{kg}$ body mass of caffeine) trials, $M \pm S D . *$ Significantly higher than PLA $(p<.05)$. $†$ Significantly higher than presupplement within trial $(p<.05)$. Values are expressed as a percentage of presupplement value.

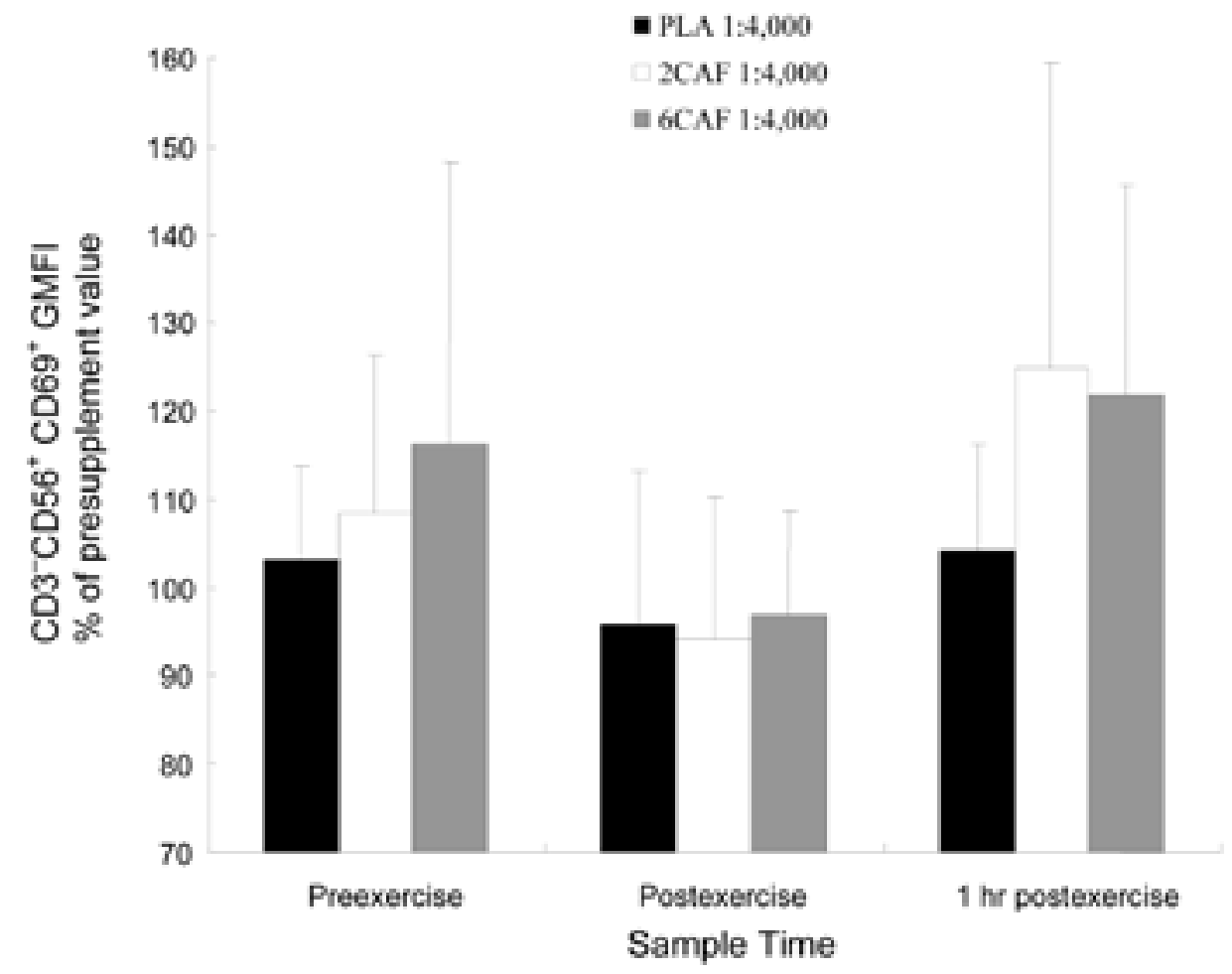

Figure 3(b) - Geometric mean fluorescence intensity of CD69 expression on 1:4,000 antigen-stimulated $\mathrm{CD}^{-} \mathrm{CD}^{-} 6^{+}$natural killer cells within the circulating lymphocyte population during PLA ( $0 \mathrm{mg} / \mathrm{kg}$ body mass of caffeine), $2 \mathrm{CAF}$ ( $2 \mathrm{mg} / \mathrm{kg}$ body mass of caffeine), and $6 \mathrm{CAF}$ ( $6 \mathrm{mg} / \mathrm{kg}$ body mass of caffeine) trials, $M \pm S D$. Values are expressed as a percentage of presupplement value. 


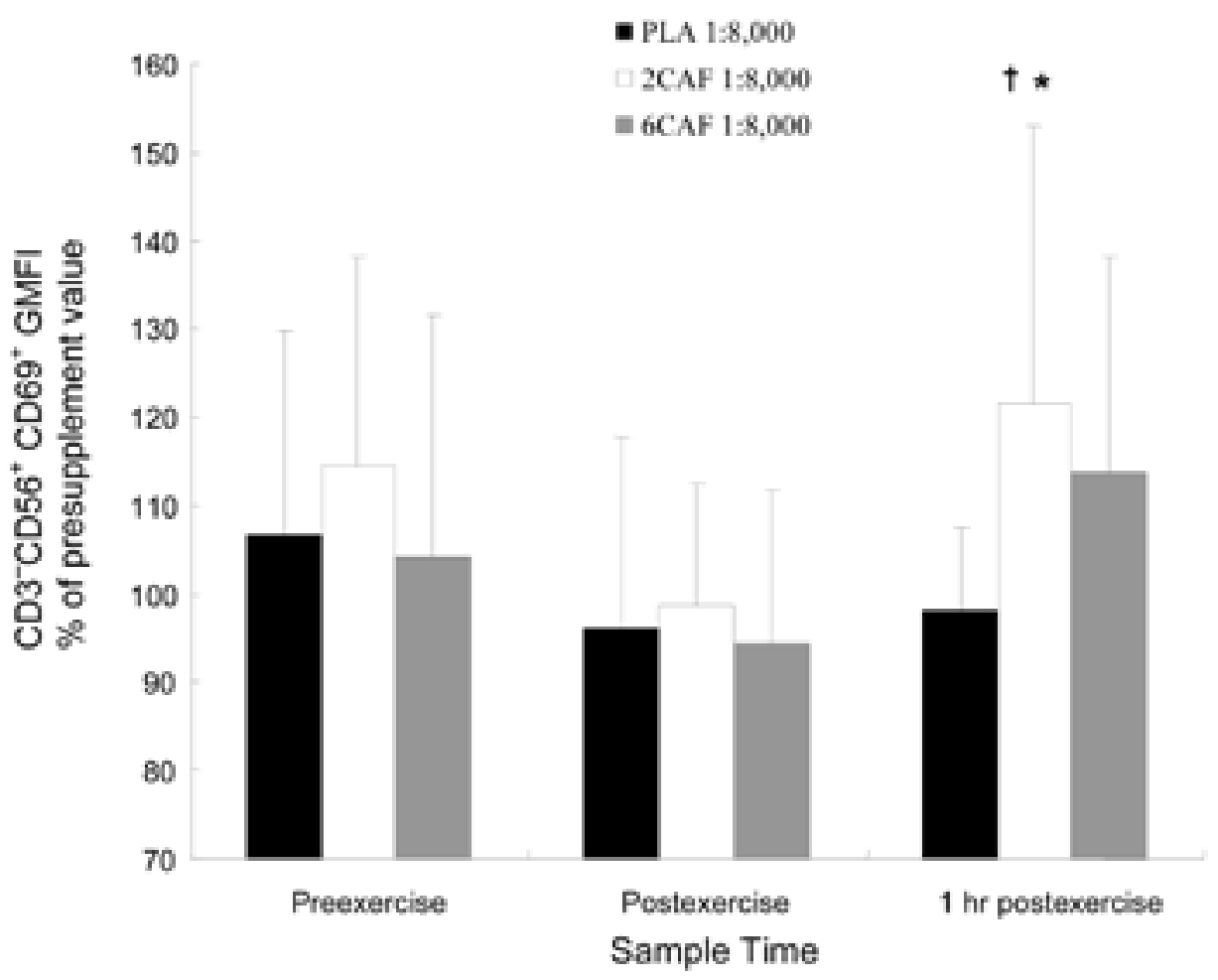

Figure 3(c) - Geometric mean fluorescence intensity of CD69 expression on 1:8,000 antigen-stimulated CD3 ${ }^{-} \mathrm{CD}^{-} 6^{+}$natural killer cells within the circulating lymphocyte population during PLA ( $0 \mathrm{mg} / \mathrm{kg}$ body mass of caffeine), $2 \mathrm{CAF}(2 \mathrm{mg} / \mathrm{kg}$ body mass of caffeine), and $6 \mathrm{CAF}(6 \mathrm{mg} / \mathrm{kg}$ body mass of caffeine) trials, $M \pm S D$. *Significantly higher than PLA $(p<.05)$. $†$ Significantly higher than presupplement within trial $(p<.05)$. Values are expressed as a percentage of presupplement value.

interaction $=.09$; Figure $3[\mathrm{~b}])$, and the GMFI of CD69 expression on antigen-stimulated $(1: 8,000) \mathrm{CD}^{-} \mathrm{CD}^{+} 6^{+}$ cells was significantly higher with $2 \mathrm{CAF} 1 \mathrm{hr}$ postexercise than with PLA $(p<.05$; Figure $3[\mathrm{c}])$. There were no differences between $2 \mathrm{CAF}$ and $6 \mathrm{CAF}$ with either dose of antigen (Figures $3[\mathrm{~b}]$ and $3[\mathrm{c}]$, respectively).

\section{Discussion}

The findings of the current study suggest that, compared with placebo, ingesting 2 or $6 \mathrm{mg} / \mathrm{kg}$ body mass of caffeine $1 \mathrm{hr}$ before exercise is associated with increases in the natural state of activation of circulating NK cells and increases in the GMFI of CD69 expression on antigenstimulated NK cells $1 \mathrm{hr}$ after high-intensity prolonged cycling. The effects of caffeine on NK-cell activation $1 \mathrm{hr}$ after prolonged intensive cycling were not found to be dose dependent. In addition, only a large dose of caffeine $(6 \mathrm{mg} / \mathrm{kg})$ increased the trafficking of NK cells into the peripheral circulation immediately postexercise compared with placebo.

In the current study both a high and low dose of caffeine increased unstimulated and antigen-stimulated NK-cell activation $1 \mathrm{hr}$ after $90 \mathrm{~min}$ of cycling at $70 \%$ $\mathrm{VO}_{\text {peak. }}$. The apparently positive effects of caffeine on NK-cell activation may be explained by its ability to alter intracellular cAMP. The actions of adenosine via $A_{2 A}$ adenosine receptors (Priebe et al., 1990) have been shown to inhibit NK-cell function via activation of adenylate cyclase and increased intracellular cAMP concentration (Goto, Herberman, Maluish, \& Strong, 1983), and the actions of adenosine via $A_{1}$ adenosine receptors have been shown to enhance NK-cell function via suppression in cAMP (Goto et al., 1983). It is known that caffeine is a nonselective adenosine-receptor antagonist. Therefore, it is suggested that both the high and low dose of caffeine acted to impede the adenosine-mediated increase in intracellular cAMP concentration in NK cells via antagonism of $\mathrm{A}_{2 \mathrm{~A}}$ adenosine receptors (Raskovalova et al., 2006). Although plasma adenosine concentration was not measured in this study, it has been reported in rats that doses of caffeine corresponding to those used in this study increased plasma concentrations of adenosine via adenosine-receptor blockade in a dose-dependent manner (Conlay, Conant, deBros, \& Wurtman, 1997).

Caffeine also has the potential to reduce NK-cell function indirectly via its ability to increase the release of epinephrine (Graham, 2001). Epinephrine stimulates $\beta_{2}$ adrenoreceptors on NK cells and in turn increases the level of intracellular cAMP, leading to an inhibition of NK-cell function (Murray et al., 1992). Because both caffeine doses in this study increased, rather than decreased, NK-cell activation $1 \mathrm{hr}$ after exercise it is unlikely that epinephrine played a principal role in NK-cell activation 
here. However, it should be noted that any effect of caffeine on antigen-stimulated NK-cell activation is most likely the net result of a number of stimulatory and inhibitory influences. Therefore, in the current study it could be argued that $\mathrm{A}_{2 \mathrm{~A}}$ adenosine-receptor antagonism may have exerted a stronger influence on NK-cell function than enhanced adrenergic stimulation.

In the current study a high dose of caffeine increased the trafficking of NK cells into the circulation immediately after exercise cessation compared with placebo. Epinephrine is known to modulate the expression of adhesion molecules on NK cells, leading to increased mobilization of these cells into the circulation after highintensity exercise (Benschop, Rodriguez-Feuerhahn, \& Schedlowski, 1996; Nagao, Suzui, Takeda, Yagita, \& Okumura, 2000). With this in mind, an alternative action of caffeine in this study might have been to influence an epinephrine-mediated mobilization into the peripheral circulation of a specific population of NK cells with an activated phenotype or with increased propensity for activation when stimulated. Although plasma epinephrine concentration was not measured in this study, our participants, exercise protocol, and serum caffeine concentration after exercise on the $6 \mathrm{mg} / \mathrm{kg}$ caffeine dose are comparable to those of Walker et al. (2006), who found a significantly higher plasma adrenaline concentration after exercise with $6 \mathrm{mg} / \mathrm{kg}$ caffeine than with placebo (current study $44 \mu \mathrm{M}$, Walker et al. $46 \mu \mathrm{M}$ ). Although high doses of caffeine (6 and $9 \mathrm{mg} / \mathrm{kg}$ ) appear to increase plasma concentrations of epinephrine, it has been reported that a low caffeine dose $(3 \mathrm{mg} / \mathrm{kg})$ has little effect in increasing plasma epinephrine concentration in response to highintensity exercise (Graham \& Spriet, 1995). This may help explain why in the current study NK-cell recruitment into the circulation after exercise was higher with 6CAF, with no differences between 2CAF and PLA at this time, and why there was a higher overall number of naturally activated NK cells in the peripheral circulation with 6CAF than with PLA and 2CAF.

However, we should bear in mind that this study used whole-blood cultures when stimulating cells. Although whole-blood cultures are the closest one can get to in vivo conditions in terms of retaining the proximity between leukocytes and extracellular milieu (Gleeson, 2007), they make it difficult to ascertain whether the vaccine used in this study directly affected NK-cell activation or exerted its effects on other bystander cells in the culture (i.e., monocytes or T cells) that subsequently influenced NK-cell activation. Stimulating NK-cell cultures depleted of T cells and monocytes could help ascertain whether the Pediacel vaccine used in this study directly activated NK cells.

This study is the first to report apparently positive effects of a low dose of caffeine on antigen-stimulated NK-cell activation $1 \mathrm{hr}$ after high-intensity exercise. Furthermore, the study has demonstrated that a low dose of caffeine appears to exert effects on NK-cell activation 1 $\mathrm{hr}$ after prolonged intensive cycling similar to those of a dose 3 times as large. This is a significant finding because many athletes only ingest small amounts of caffeine to enhance athletic performance (Chester \& Wojek, 2008), and it suggests that a low dose of caffeine, as well as being ergogenic (Cox et al., 2002), may have the potential to strengthen an athlete's first line of defense against infectious agents after high-intensity exercise. However, it is difficult to extrapolate an enhancement in NK-cell activation to an enhancement of an athlete's overall immunity $1 \mathrm{hr}$ after high-intensity exercise; the enhancement in this study relates to one particular cellular response and as such may not accurately represent what is happening to the rest of the athlete's immune system. Future use of in vivo cell-mediated immune-function tests would help shed light on any effect of caffeine ingestion on wholebody cell-mediated immunity.

Although in this study the effects of ingesting $6 \mathrm{mg} /$ $\mathrm{kg}$ body mass of caffeine on antigen-stimulated NKcell activation did not reach statistical significance, it showed a trend for increased cellular responses that was comparable to that observed with ingestion of $2 \mathrm{mg} / \mathrm{kg}$ body mass. Pilot work from our group has previously demonstrated that $6 \mathrm{mg} / \mathrm{kg}$ body mass of caffeine was effective at increasing antigen-stimulated NK-cell activation after an identical exercise protocol (Fletcher et al., 2008). The current participants are comparable to those used for our pilot work, and diet, exercise, and caffeine controls before the trial were identical to the former study. However, interindividual variations in responses were greater here than in our pilot work. This may relate to individual differences in habitual caffeine intake, because caffeine consumption here was more varied among the participants than in our previous work. Indeed, large interindividual differences in athletes' physiological and performance responses to the effects of caffeine have been reported (Desbrow, Barrett, Minahan, Grant, \& Leveritt, 2009; Skinner, Jenkins, Coombes, Taaffe, \& Leveritt, 2010). Future investigations into the effects of caffeine on specific groups of caffeine users-that is, light, moderate, or high users - would help clarify reasons for such variability.

In conclusion, the findings of the current study suggest that both a high and low dose of caffeine are associated with an increase in the natural state of activation of NK cells, in addition to having positive effects on antigenstimulated NK-cell activation $1 \mathrm{hr}$ after high-intensity prolonged cycling. However, there was no obvious effect of caffeine dose on these responses. It is suggested that these findings reflect an overriding $\mathrm{A}_{2 \mathrm{~A}}$ antagonistic effect of caffeine or a caffeine-influenced epinephrine-mediated mobilization of a specific population of activated NK cells. Most likely it is a combination of the two. Despite both doses of caffeine having a positive influence on NK-cell activation $1 \mathrm{hr}$ after high-intensity exercise, the clinical significance of these findings in terms of subsequent infection risk is as yet unclear.

\section{Acknowledgments}

The authors wish to thank Kevin Deighton and Daniel Walsh for their help with data collection. 


\section{References}

Andoniou, C.E., Andrews, D.M., \& Degli-Esposti, M.A. (2006). Natural killer cells in viral infection: More than just killers. Immunological Reviews, 214, 239-250.

Benschop, R.J., Rodriguez-Feuerhahn, M., \& Schedlowski, M. (1996). Catecholamine-induced leukocytosis: Early observations, current research, and future directions. Brain, Behavior, and Immunity, 10, 77-91.

Bishop, N.C., Smith, A.E., Fitzgerald, C., Porter, P., \& Scanlon, G.A. (2005). Effect of caffeine ingestion on leukocyte counts and lymphocyte activation following strenuous cycling. European Journal of Applied Physiology, 93, 606-613.

Borrego, F., Robertson, M.J., Ritz, J., Peña, J., \& Solana, R. (1999). CD69 is a stimulatory receptor for natural killer cell and its cytotoxic effect is blocked by CD94 inhibitory receptor. Immunology, 97(1), 159-165.

Chester, N., \& Wojek, N. (2008). Caffeine consumption amongst British athletes following changes to the 2004 WADA prohibited list. International Journal of Sports Medicine, 29(6), 524-528.

Conlay, L.A., Conant, J.A., deBros, F., \& Wurtman, R. (1997). Caffeine alters plasma adenosine levels. Nature, 389, 136.

Cox, G.R., Desbrow, B., Montgomery, P.G., Anderson, M.E., Bruce, C.R., Macrides, T.A., . . Burke, L.M. (2002). Effect of different protocols of caffeine intake on metabolism and endurance performance. Journal of Applied Physiology, 93(3), 990-999.

Desbrow, B., Barrett, C.M., Minahan, C.L., Grant, G.D., \& Leveritt, M.D. (2009). Caffeine, cycling performance, and exogenous $\mathrm{CHO}$ oxidation: A dose-response study. Medicine and Science in Sports and Exercise, 41, 17441751.

Dill, D.B., \& Costill, D.L. (1974). Calculation of percentage changes in volumes of blood, plasma, and red-cells in dehydration. Journal of Applied Physiology, 37(2), 247-248.

Fletcher, D.K., Bowry, P., Noon, M., \& Bishop, N.C. (2008). The effect of caffeine ingestion on natural killer lymphocyte activation following prolonged strenuous cycling [abstract]. Archivos de Medicina del Deporte Review., $128,515$.

Gleeson, M. (2007). Immune function in sport and exercise. Journal of Applied Physiology, 103, 693-699.

Goto, T., Herberman, R.B., Maluish, A., \& Strong, D.M. (1983). Cyclic AMP as a mediator of prostaglandin E-induced suppression of human natural killer cell activity. Journal of Immunology (Baltimore, MD.: 1950), 130(3), 1350-1355.

Graham, T.E. (2001). Caffeine and exercise: Metabolism, endurance and performance. Sports Medicine (Auckland, N.Z.), 31(11), 785-807.

Graham, T.E., \& Spriet, L.L. (1995). Metabolic, catecholamine, and exercise performance responses to various doses of caffeine. Journal of Applied Physiology, 78(3), 867-874.

Green, K.J., Rowbottom, D.G., \& Mackinnon, L.T. (2003). Acute exercise and T-lymphocyte expression of the early activation marker CD69. Medicine and Science in Sports and Exercise, 35(4), 582-588.

Hartley, L.H., Mason, J.W., Hogan, R.P., Jones, L.G., Kotchen, T.A., Mougey, E.H., . . Ricketts, P.T. (1972). Multiple hormonal responses to prolonged exercise in relation to physical training. Journal of Applied Physiology, 33(5), 602-606.
Jenkins, N.T., Trilk, J.L., Singhal, A., O'Connor, P.J., \& Cureton, K.J. (2008). Ergogenic effects of low doses of caffeine on cycling performance. International Journal of Sport Nutrition and Exercise Metabolism, 18(3), 328-342.

Kantamala, D., Vongsakul, M., \& Satayavivad, J. (1990). The in vivo and in vitro effects of caffeine on rat immune cells activities: B, T and NK cells. Asian Pacific Journal of Allergy and Immunology, 8(2), 77-82.

Kappel, M., Tvede, N., Galbo, H., Haahr, P.M., Kjaer, M., Linstow, M., ... Pedersen, B.K. (1991). Evidence that the effect of physical exercise on NK cell activity is mediated by epinephrine. Journal of Applied Physiology, 70(6), 2530-2534.

McFarlin, B.K., Flynn, M.G., Stewart, L.K., \& Timmerman, K.L. (2004). Carbohydrate intake during endurance exercise increases natural killer cell responsiveness to IL-2. Journal of Applied Physiology, 96(1), 271-275.

Murray, D.R., Irwin, M., Rearden, C.A., Ziegler, M., Motulsky, H., \& Maisel, A.S. (1992). Sympathetic and immune interactions during dynamic exercise: Mediation via a 32-adrenergic-dependent mechanism. Circulation, 86(1), 203-213.

Nagao, F., Suzui, M., Takeda, K., Yagita, H., \& Okumura, K. (2000). Mobilization of NK cells by exercise: Downmodulation of adhesion molecules on NK cells by catecholamines. American Journal of Physiology. Regulatory, Integrative and Comparative Physiology, 279(4), R1251-R1256.

Priebe, T., Platsoucas, C.D., \& Nelson, J.A. (1990). Adenosine receptors and modulation of natural killer cell activity by purine nucleosides. Cancer Research, 50(14), 4328-4331.

Raskovalova, T., Lokshin, A., Huang, X., Jackson, E.K., \& Gorelik, E. (2006). Adenosine-mediated inhibition of cytotoxic activity and cytokine production by IL-2/ NKp46-activated NK cells: Involvement of protein kinase A isozyme I (PKA I). Immunologic Research, 36, 91-100.

Shephard, R.J. (2003). Adhesion molecules, catecholamines and leucocyte redistribution during and following exercise. Sports Medicine (Auckland, N.Z.), 33(4), 261-284.

Skinner, T.L., Jenkins, D.G., Coombes, J.S., Taaffe, D.R., \& Leveritt, M.D. (2010). Dose response of caffeine on 2000-m rowing performance. Medicine and Science in Sports and Exercise, 42, 571-576.

Timmons, B.W., Tarnopolsky, M.A., Snider, D.P., \& Bar-Or, O. (2006). Puberty effects on NK cell responses to exercise and carbohydrate intake in boys. Medicine and Science in Sports and Exercise, 38(5), 864-874.

Vizi, E., Huszar, E., Csoma, Z., Boszormenyi-Nagy, G., Barat, E., Horvath, I., . . Kollai, M. (2002). Plasma adenosine concentration increases during exercise: A possible contributing factor in exercise-induced bronchoconstriction in asthma. The Journal of Allergy and Clinical Immunology, 109(3), 446-448.

Walker, G.J., Caudwell, P., Dixon, N., \& Bishop, N.C. (2006). The effect of caffeine ingestion on neutrophil oxidative burst responses following prolonged cycling. International Journal of Sport Nutrition and Exercise Metabolism, 16(1), 24-35.

Ziegler, S.F., Ramsdell, F., \& Alderson, M.R. (1994). The activation antigen CD69. Stem Cells (Dayton, Ohio), $12(5), 456-465$. 